УДК 37 (091) (477)

DOI: $10.35619 /$ iiu.v1i10.205

Ящук Інна

доктор педагогічних наук, професор, декан факультету початкової освіти та філології Хмельницької гуманітарно-педагогічної академії,

м. Хмельницький, Україна, ORCID: 0000-0003-4028-3327

e-mail: yashchuk.ip@gmail.com

\title{
МЕТОДИЧНІ АСПЕКТИ ПРИНЦИПУ ДИТИНОЦЕНТРИЗМУ У ПЕДАГОГІЧНІЙ СИСТЕМІ ВАСИЛЯ СУХОМЛИНСЬКОГО
}

\begin{abstract}
Анотація. У статті схарактеризовані методичні аспекти принципу дитиноцентризму в педагогічній системі В. О. Сухомлинського.

Особливості дидактичного аспекту висвітлено з позиції єдності таких педагогічних явищ: викладання як системи діяльності 3 метою створення умов для навчальнопізнавальної діяльності учнів; учіння як цілеспрямованої, мотивованої, саморегулюючої, перетворюючої діяльності з оволодіння, перетворення, збереження й застосування системи знань, в результаті якої відбувається розвиток й виховання зростаючої особистості; саморозвиток учасників процесу навчання як активної, послідовної, прогресивної і незворотної зміни соціально-психологічного статусу особистості учня у процесі навчання у зв'язку з його потребою у самоудосконаленні.

3'ясовано, що принцип дитиноцентризму в Павлиській школі реалізувався на знанні вчителем особистості кожного учня, мотивації навчання, підтримці його первинного бажання вчитися; формуванні знань необхідних для самореалізації у суспільстві; орієнтації на розвиток індивідуальних особливостей кожної дитини, що сприяють іï особистісному зростанню та успішній самореалізації у суспільстві; педагогіці партнерства між усіма учасниками навчально-виховного процесу.

Розкрито особливості виховного аспекту принципу дитиноцентризму, що полягають в організації позакласної та самоосвітньої діяльності, спрямованої на гармонійне поєднання інтересів усіх учасників виховного процесу: вихованця, який прагне вільного саморозвитку і збереження своєї індивідуальності; школи, стратегічна мета якої - забезпечення школярів знаннями для успішної їх реалізації у суспільстві; суспільства, зусилля якого спрямовані на моральний саморозвиток особистості; держави, зацікавленої в тому, щоб школярі зростали гідними громадянами своєї країни

Розкрито потенціал педагогічної системи В. О. Сухомлинського щодо реалізації принципу дитиноцентризму в освітній процес сучасної школи.
\end{abstract}

Ключові слова: принцип дитиноцентриму, В. О. Сухомлинський, Павлиська школа, дидактичний й виховний аспекти, саморозвиток школяра.

Постановка проблеми. Цивілізаційний поступ України в умовах інформаційного суспільства неможливий без успішної реалізації стратегічних завдань освітньої реформи, яка нині здійснюється відповідно до оновленої законодавчої бази, що відображена в Законах України «Про повну загальну середню освіту» (2018), «Про вищу освіту» (2014), Національній доктрині розвитку освіти в Україні на 2012-2021 роки, Концепції «Нова українська школа» (2016), програмі «Демократична школа: підтримка освітніх реформ в Україні» (2018-2021pp) та ін.

Важливою умовою успішності реформування $є$ трансформація методології освіти, що полягає у зміні ціннісної освітньої парадигми, перехід до гуманістичної, особистісно орієнтованої освіти, спрямованої на різнобічний розвиток особистості учня, на формування ініціативної, активної людини, громадянина з яскраво вираженою 
творчою індивідуальністю, тобто, яка передбачає вільний розвиток особистості на засадах гуманізму, демократизму, дитиноцентризму.

У сучасній освіті дитиноцентризм розглядається як «один із чинників розвитку та якісного прориву в національній системі освіти, і передбачає створення умов для розвитку гармонійної, морально досконалої, соціально активної, професійно компетентної й саморозвивальної особистості» (Програма «Нова українська школа» у поступі до цінностей»); «наскрізний принцип виховного процесу, що орієнтує на незаперечне визнання цінності у житті людини періоду дитинства, соціальні, вікові та індивідуальні потреби учня в освітньому процесі, його активну участь у шкільному житті та прийнятті рішень» (Нова українська школа. Концептуальні засади реформування середньої школи).

Аналіз останніх досліджень 3 проблеми. Дослідження реалізації принципу дитиноцентризму в діяльності навчальних закладів детермінувало звернення до педагогічних i науково-методичних джерел вітчизняних i зарубіжних вчених, які здійснили значний внесок у формування нового підходу до розвитку освітньої системи в цілому, зокрема до наукових праць В. Кременя, О. Локшиної (трансформація змісту освіти, трансформація особистості), Я. Гнітецького, З. Квецінського, Й. Томаса, А. Тхожевського (етіологія та парадигми освітніх реформ), В. Лексина, О. Швецова (стратегія й постулати запровадження освітніх реформ), О. Епштейна (критерії ефективності реформ), Л. Березівської (реформування шкільної освіти в Україні), Л. Гриневич (освітні реформи), О. Савченко, О. Ляшенко (реформування початкової освіти, реформування змісту освіти), О. Сухомлинської (реформаторська педагогіка, реформування виховної складової освіти, політика реформування в історичному контексті) та ін.

Цінним джерелом реалізації ідеї принципу дитиноцентризму в освіті $є$ педагогічна спадщина В.О.Сухомлинського, теоретично виражена в його працях «Вірте в людину», «Людина неповторна», «Як виховати справжню людину», «Дума про людину», «Шлях до серця дитини», «Проблеми виховання всебічно розвиненої особистості», «Методика виховання колективу», «Серце віддаю дітям», і практично втілена у систему роботи Павлиської школи.

Мета статті: схарактеризувати методичні аспекти принципу дитиноцентризму в $\begin{array}{lllll}\text { педагогічній спадщині } & \text { В. О. Сухомлинського } 3 & \text { позиції його актуальності та }\end{array}$ інноваційності у контексті сучасної освітньої реформи.

Виклад основного матеріалу дослідження. Як засвідчує аналіз педагогічної спадщини В.Сухомлинського, особливістю навчально-виховної системи Павлиської школи, очолюваної Василем Сухомлинським упродовж 22 років, є поєднання трьох значущих педагогічних явищ: викладання, учіння та саморозвиток школярів. Викладання розглядається як система діяльності 3 метою створення умов для навчально-пізнавальної діяльності учнів, зміст яких складають: система знань 3 конкретного предмета, уміння формувати систему знань для заданого рівня розвитку учнів, розвиток пізнавальних інтересів і комунікативних умінь учнів. Учіння виступає як цілеспрямована, мотивована, саморегулююча, перетворююча діяльність 3 оволодіння, перетворення, збереження і застосування системи знань, в результаті якої відбувається розвиток і виховання особистості. Саморозвиток учасників процесу навчання пов'язаний 3 активними, послідовними, прогресивними і незворотними змінами соціально-психологічного статусу особистості учня у процесі навчання i участі в позаурочній і позакласній виховній роботі.

Основний ресурс дидактичної ситами Василя Сухомлинського - урок, який великий педагог вважав дзеркалом загальної і педагогічної культури вчителя, мірою його інтелектуального багатства, показником його кругозору й ерудиції. Важливою складовою уроку в школі була організація мислительної діяльності, іiі зв'язок 3 оточуючим середовищем. Тому навчально-виховна діяльність на уроці будувалася 3 позиції напруженої розумової праці, що сприяла оволодінню учнями новими 
знаннями, розвитку їх пізнавальної активності, творчої ініціативи. 3 цією метою вчителі застосовували специфічні прийоми мислення на уроках. «Мислителем ваш вихованець стає лише тоді, - писав, звертаючись до вчителів В. Сухомлинський, - коли ви приходите до нього з думкою, запалюєте його своєю допитливістю, жадібністю і ненаситністю до пізнання, передаєте йому почуття гордості мислителя» (Сухомлинський, 1977, с. 123). Тому процес навчання характеризувався аналізом абстрактних фактів і явищ, подій реальної діяльності - учні вирішували задачі, складені в процесі спостережень, досліджували зв'язки між явищами і предметами; придумували задачі 3 геометрії 3 використанням фігур, виготовлених власними руками; рівняння 3 алгебри формувалися відповідно до залежностей, встановленими в процесі трудової діяльності на пришкільній ділянці, у шкільній майстерні, на пасіці тощо. У такий спосіб навчання розглядалося як живе джерело мислительної діяльності вчителя й учня, що робило процес навчання захоплюючим, творчим, пошуковим, дослідницьким. Саме дослідження В. Сухомлинський вважав основою мислення, «без уміння досліджувати немає живої думки - значить, немає і міцних грунтових знань» (Сухомлинський, 1976 а, с.393).

Яскравим прикладом реалізації принципу дитиноцентризму у навчальновиховному процесі школи було уміння педагогів надати навчально-пізнавальній діяльності учнів пошуково-дослідницького характеру. Тому широко застосовувався такий методичний прийом, як створення на уроці проблемної ситуації, коли вчитель, пояснюючи новий матеріал, залишав його частину матеріалу ніби недомовленою. Це слугувало своєрідним «запалом» для мислення школярів, породжувало у них численні запитання, викликало потребу продовжити роздуми в позаурочний час. У школі практикувалося проведення лабораторних та практичних занять, під час яких учні моделювали, конструювали, здійснювали розрахунки, складали підсумкові таблиці та графіки. Великого значення також мало спонукання учнів до самостійного складання завдань, підготовка наукових доповідей і рефератів.

Активній участі в дослідно-експериментальній i винахідницькій діяльності школярів сприяла практика проведення уроків в бібліотеці, лабораторіях, майстернях, на пришкільній ділянці. Ця ідея В. Сухомлинського $є$ актуальною й дотепер i знаходить своє підтвердження в концепції Нової української школи: «Формуванню навичок наукової діяльності та винахідництва слугуватимуть сучасні лабораторії, а також програми доступу дітей до наукових музеїв, обсерваторій, відкритих навчальних курсів та інших ресурсів» (Нова українська школа. Концептуальні засади реформування середньої школи).

Принцип дитиноцентризму в Павлиській школі реалізувався на знанні вчителем особистості кожного учня та мотивації навчання, підтримці його первинного бажання вчитися. «Без знання дитини нема школи, нема виховання, нема справжнього педагога і педагогічного колективу» (Сухомлинський, 1976 а, с. 449), позаяк «знати дитину - це та найголовніша точка, де стикаються теорія і практика педагогіки, де сходяться всі нитки педагогічного керівництва шкільним колективом» (Сухомлинський, 1976 a, с.441). Тому формування знань, необхідних для самореалізації школярів у суспільстві, орієнтація на розвиток індивідуальних особливостей кожної дитини, що сприяли іiі особистісному зростанню у навчально-виховному процесі Павлиської школи пов'язувалися із активними методами навчання, які стимулювали пізнавальні процеси, передбачали включення учнів у спілкування, у творчу продуктивну діяльність. Зокрема:

- застосування раніше набутих знань і умінь для набуття нових (репродуктивний $\mathrm{i}$ самостійний аналіз фактів, предметів, явищ);

- самостійне вироблення уміння застосовувати знання, отримані на уроках (виконання практичних завдань - вправ, розрахунків, задач, монтування діючих моделей машин і механізмів); 
- спостереження за природними джерелами (природні явища, предмети оточуючого середовища, трудові процеси); спостереження, які передують вивченню нового матеріалу;

- дослідження явищ, процесів (організація спостережень, експериментів як у природному середовищі, так і в лабораторії).

Активні методи поєднувалися 3 репродуктивними бесідами, вправами i завданнями.

Реалізації системи методів навчання в дидактичній системі В. Сухомлинського сприяла освітня мета, спрямована на моральну, розумову, практичну і психологічну підготовку до навчальної і трудової діяльності, розкриття в кожного учня індивідуальних здібностей. В. Сухомлинський був переконаний, що реалізація принципу дитиноцентризму нерозривно пов'язана 3 урахуванням індивідуальних здібностей, нахилів, особливостей школярів. Тому навчальна та позакласна діяльність педагогічного колективу школи спрямовувалася на те, «щоб у школі не було жодного учня, який нічим не цікавиться, якого ніщо не хвилює і не захоплює, який з однаковою байдужістю вчить і математичні формули, і ліричні вірші, щоб кожен вихованець 3 перших днів свого перебування в школі чимось захопився, щось полюбив, розвинув свої творчі здібності, вийшов 3 іï стін 3 певним життєвим покликанням» (Сухомлинський, 1977, с.123). Вчителю «треба побачити, пізнати, зрозуміти дитину... Пізнайте їі такою, якою вона $\epsilon$. Не намагайтеся змінити, переломити, перебудувати те, що створила в своїй таємничій майстерні природа ...» (Сухомлинський, 1976 b, с. 214). Завдання школи В. Сухомлинський вбачав у тому, щоб «розпізнати, виявити, розкрити, виростити, виплекати в кожного учня його неповторно індивідуальний талант...», (Сухомлинський, 1976 с, с. 96).

Саме 3 цією метою педагогічним колективом школи була розроблена методика такої форми роботи, як година улюбленої праці. Працюючи за визначеним планом як самостійно, так і під керівництвом учителя, учні могли по 2-3 години займатися улюбленою справою, розвиваючи свої здібності, уподобання, удосконалюючи знання й уміння: одні працювали у столярній майстерні, інші монтували моделі з металу, працювали в саду чи в куточку живої природи. Діяльність в ці години уявлялася павлиським педагогам як задоволення багатогранних трудових та інтелектуальних запитів, як поєднання роботи думки і рук. «В час улюбленої праці зусилля творчої думки i фізична праця кожного школяра зливаються воєдино», - писав В.Сухомлинський (Сухомлинський, 1970, с.164).

Тож акцент в навчально-виховному процесі Павлиської школи ставився на розширення уявлень школяра про навколишній світ, розвиток у нього критичного мислення і незалежності поведінки, на формування системи моральних цінностей, а також умінь і навиків самостійного отримання і застосування інформації.

Специфіка сучасної системи освіти відповідно до вимог Нової української школи полягає в тому, що вона повинна бути здатна не тільки озброювати учня знаннями, а й формувати у нього потребу в безперервному самостійному і творчому підході до оволодіння новими знаннями, уміннями і створювати можливості до відпрацювання умінь і навичок самоосвіти. I тут ми бачимо пряму паралель між ідеями педагога i положенням Концепції «Нова українська школа».

Самоосвіта розглядалася В. Сухомлинським не як механічне поповнення знань, а як акт живих людських взаємостосунків, суть яких полягає в обміні знаннями, уміннями: «передаючи знання людям, людина пізнає іншу людину і сама себе» (Сухомлинський, 1970, с. 164); як один із засобів розкриття інтелектуального потенціалу школяра, як результат зрілості, усвідомлення власної життєвої позиції, готовності до вибору майбутньої професійної діяльності.

Видами діяльності з самоосвіти школярів в Павлиській школі були: самостійне вивчення фактів, подій дійсності (педагоги розробляли спеціальну систему завдань до самоосвіти); самостійне читання як первинне сприйняття знань (учням пропонувалися 
розділи шкільної програми для самостійного вивчення; читання додаткової літератури (у поєднанні з спостереженнями, дослідницькою діяльністю, оглядом макетів, діаграм, таблиць, схем, таблиць, картинок, малюнків, моделей); дослідження фактів живого мовлення (речення, словосполучення, слово). Тобто, в процесі самостійної пізнавальної діяльності учні самостійно формулювали пізнавальні цілі; описували модель результату пізнавальної діяльності; підбирали або створювали способи і засоби конкретних видів діяльності; виконували заплановані дії, оцінювали і усвідомлювали ступінь досягнення запланованих результатів; усвідомлювали причини невідповідності отриманих результатів пізнання від запланованих або очікуваних; оцінювали свій емоційний стан і планували способи подолання труднощів,

Самоосвітня діяльність здійснювалася і в процесі виконання домашньої роботи. Вчитель таким чином формулював питання, щоб вони не передбачали переказ підручника, а стимулювали «аналіз, дослідження, порівняння - ці форми розумової праці повинні пронизувати домашні завдання, які поєднували у собі читання книги із спостереженням за працею (Сухомлинський, 1977, с.253).

Роль вчителя в цьому випадку як творчого педагога, який допомагав учневі реалізуватися, полягав у тому, аби в консультаційному порядку пояснити йому труднощі й переваги обраного ним шляху, розказати про інші шляхи та способи вирішення проблеми, про нові можливості та прискорення їх втілення. Це підвищувало ефективність навчання, розвивало емоційно-вольову сферу учня, який самостійно вибирав шляхи свого навчання. При цьому школяр усвідомлював, що шлях можна змінити. I саме вчитель може підказати йому як зробити ці зміни найефективніше. Звідси і довіра до вчителя, повага до його особистості.

Індивідуальному розвитку учня в школі сприяла гурткова діяльність за інтересами. Гуртки, яких нараховувалося в школі більше восьмидесяти, розподілялися на блоки: науково-предметні: математичний, фізичний, хімічний, біологічний, історичний, астрономічний, географічний; за різними видами творчої діяльності: юних конструкторів, слюсарів-моделістів, токарів, столярів, тваринників, механізаторів, садоводів і лісоводів, бджолярів, селекціонерів, механізаторів, радіотехніків, дослідників природних багатств рідного краю, електротехніків, літературно-творчий, драматичний, музичний. Беручи в них участь, учні переконувалися, що шкільна освіта - лише перший крок на шляху до вершин науки і знань, а для досягнення високих освітніх результатів необхідно вчитися все життя.

Оскільки заняття в гуртках науково-предметного блоку проводилися у формі живих, насичених яскравими, цікавими фактами повідомлень, доповідей, рефератів, то школярі не тільки удосконалювали і поглиблювали свої знання 3 навчальних предметів, а й нерідко вивчали питання, які виходили за межі шкільної програми, що сприяло формуванню потреби у самостійному пошуку і пізнанні нового. Тобто, під час гурткової роботи застосовувався практико-орієнтований підхід, що спонукав педагога до активізації особистісних якостей, творчих та інтелектуальних зусиль, гуртківця - до створення особистого продукту в тій чи іншій формі. Гуртки за різними видами творчої діяльності забезпечували умови для цілеспрямованого творчого, інтелектуального й духовного розвитку школярів у галузі окремих наук, а також сприяли розв'язанню проблеми раннього професійного вибору, професійного самовизначення і життєвого проектування школяра.

Організована система виховної роботи на основі занять в гуртках 3 метою виховання на основі розвитку природних задатків, здібностей, уподобань має безпосереднє відношення до реалій сучасної школи. Як зазначив В. Кремінь, нині «...є необхідність якомога більше наблизити навчання і виховання кожної дитини до іiі сутності, конкретних здібностей, майбутньої життєвої траєкторії людини. Це явище я називаю дитиноцентризмом в освіті» (Нова українська школа: порадник для вчителя, 2018, с. 17). 
Яскравим прикладом застосування принципу дитиноцентризму у педагогічній системі Василя Сухомлинського $\epsilon$ духовне спілкування педагога зі своїми вихованцями. Під духовним спілкуванням Сухомлинський мав на увазі повсякденні зустрічі в товариській, невимушеній атмосфері, під час яких вчитель вводив своїх учнів у світ науки, ставав для них людиною високої інтелектуальної культури, який запалює в їх серцях спрагу знань, утверджує почуття поваги до думки, науки. Така єдність вчителів і учнів виникала в тому випадку, коли вони спільно переживали подію, явище, що мало яскраво виражене духовно-моральне забарвлення. Палке слово педагога створювало при цьому відчуття справжньої єдності поглядів, почуттів і переконань, без чого неможлива інтелектуальна атмосфера i той моральнопсихологічний клімат, у якому розвивається і утверджується почуття радості пізнання. Такі індивідуальні бесіди Василь Олександрович вважав одним 3 найбільш цінних і нічим не замінних засобів педагогічного впливу, важливим засобом морального, емоційного, естетичного виховання, стимулом самовиховання.

Висновки і перспективи подальших розвідок. Здійснений аналіз дає змогу стверджувати, що принцип дитиноцентризму в педагогічній системі Василя Сухомлинського об'єднує у собі як дидактичні, так і виховні аспекти. У його основі ключова ідея - ставлення до дитини як до найвищої цінності, орієнтація на іiі особистісну спрямованість, створення умов, які забезпечують іiі вільний саморозвиток, збереження своєї індивідуальності. Вважаємо, що проблема реалізації принципу дитиноцентризму в освітньо-виховній діяльності школи Василя Сухомлинського $є$ орієнтиром у контексті реалізації Концепції Нова українська школа, оскільки педагогіка Сухомлинського на століття випереджала свій час.

До перспективних напрямів подальших наукових досліджень ми відносимо уроки мислення як засіб розумового виховання школярів в педагогічній спадщині В. Сухомлинського.

\section{СПИСОК ВИКОРИСТАНИХ ДЖЕРЕЛ}

Програма «Нова украӥнська школа у поступі до иінностей» [online]. Режим

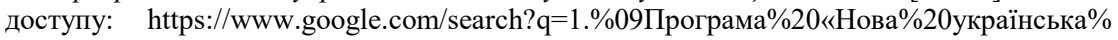
20школа\%20у\%20поступі\%20до\%20цінностей»\%20програма-02-08-2018 pdf [Дата останнього звернення 08.09.2019]

Нова українська школа. Концептуальні засади реформування середньої школи [online]. Режим доступу: https//mon.gov.ua/ storage/ app/media /zagalna\%20 serednya/ nova/ukrainska-shkola-compressed.pdf [Дата останнього звернення 08.09.2019]

Сухомлинський, В. (1977). Вибрані твори. В 5-ти т. Київ, Рад. шк., 1977. Т.3. 670c.

Сухомлинський, В. (1976 а). Розмова з молодим директором школи. Вибрані твори в 5 m. Т.4. Київ: Рад. шк. С.393-629.

Нова українська школа. Кониептуальні засади реформування середньої школи [online]. Режим доступу: https//mon.gov.ua/storage/app/media /zagalna\%20serednya /nova/ukrainska-shkola-compressed.pdf [Дата останнього звернення 08.09.2019]

Сухомлинський, В. (1976 а). Розмова з молодим директором школи. Вибрані твори в 5 m. Т.4. Київ: Рад. шк. С.393-629.

Сухомлинський, В. (1977). Вибрані твори в 5 томах. Том 5. Київ : Рад. шк. С.123.

Сухомлинський, В. (1976 b). На нашій совісті - людина. Вибрані твори в 5 томах. Том 5. Київ : Рад. шк. С. 214.

Сухомлинський, В. (1976 с). Людина неповторна. Вибрані твори в 5 томах. Том 5. Київ : Рад. шк. С. 96.

Сухомлинський, В. (1970). Народження громадянина. Київ: Радянська школа. C.164.

Сухомлинський, В. (1977). Розмова 3 молодим директором. Вибрані твори у 5 mомах. Т. 4. Київ: Радянська школа. С.253 
Нова украӥнська школа: порадник для вчителя (2018). За заг. ред. Н. М. Бібік. Київ : Літера ЛТД, 2018. с. 17. [online]. Режим доступу : https:/ mon. gov.ua/ storage/app/media/news/Новини/2018/12/12/11/20-11-2018rekviz.pdf [Дата останнього звернення 18.08.2009 р.]

\title{
REFERENCES
}

Prohrama "Nova ukrainska shkola u postupi do tsinnostei" [The Program "New Ukrainian School in Transition to Values"]. [online]. Rezhym dostupu: https://www.google.com/search?q=1.\%09Програма\%20«Нова\%20українська\%20школа\% 20y\%20поступі\%20до\%20цінностей»\%20програма-02-08-2018. (in Ukrainian)

Nova ukrainska shkola. Kontseptualni zasady reformuvannia serednoi shkoly [New Ukrainian School. Conceptual Principles of Secondary School Reform]. [online]. Rezhym dostupu: https//mon.gov.ua/storage/app/media/zagalna\%20serednya/nova/ukrainska-shkolacompressed.pdf [Data ostannoho zvernennia 08.09.2019] (in Ukrainian)

Sukhomlynskyi, V. (1977). Vybrani tvory. V 5-ty $t$. [Selected Works. In 5 vol.]. Kyiv, Rad. shk., 1977. T.3. 670 s. (in Ukrainian)

Sukhomlynskyi, V. (1976a). Rozmova z molodym dyrektorom shkoly. Vybrani tvory v 5 t. T.4. [Selected Works. In 5 vol.Vol.4]. Kyiv: Rad. shk. S.393-629. (in Ukrainian)

Nova ukrainska shkola. Kontseptualni zasady reformuvannia serednoi shkoly [New Ukrainian School. Conceptual Principles of Secondary School Reform]. [online]. Rezhym dostupu: https//mon.gov.ua/storage/app/media/zagalna\%20serednya/nova/ukrainska-shkolacompressed.pdf [Data ostannoho zvernennia 08.09.2019] (in Ukrainian)

Sukhomlynskyi, V. (1976a). Rozmova z molodym dyrektorom shkoly. Vybrani tvory v 5 t. T.4. [Selected Works. In 5 vol.Vol.4]. Kyiv: Rad. shk. S.393-629. (in Ukrainian)

Sukhomlynskyi, V. (1977). Vybrani tvory v 5 tomakh. Tom 5. [Selected Works. In 5 vol.Vol.5] K. : Rad. shk. S.123. (in Ukrainian)

Sukhomlynskyi, V. (1976b). Na nashii sovisti - liudyna. Vybrani tvory v 5 tomakh. Tom 5. [Selected Works. In 5 vol. Vol.5] Kyiv: Rad. shk. S. 214. (in Ukrainian)

Sukhomlynskyi, V. (1976v). Liudyna nepovtorna. Vybrani tvory v 5 tomakh. Tom 5. [Selected Works. In 5 vol. Vol.5] Kyiv: Rad. shk. S. 96. (in Ukrainian)

Sukhomlynskyi, V. (1970). Narodzhennia hromadianyna [Birth of a Citizen] Kyiv: Rad. shk. S.164. (in Ukrainian)

Sukhomlynskyi, V. (1977). Rozmova z molodym dyrektorom. Vybrani tvory u 5 tomakh. T. 4. [Selected Works. In 5 vol.Vol. 4]. Kyiv: Rad. Shk. S.253 (in Ukrainian)

Nova ukrainska shkola: poradnyk dlia vchytelia (2018). [New Ukrainian School. Quide to Teacher]. Za zah. red. N. M. Bibik. Kyiv : Litera LTD. s. 17. [online]. Rezhym dostupu : https://mon.gov.ua/storage/app/media/news/Novyny/2018/12/12/11/20-11-2018rekviz.pdf [Data ostannoho zvernennia 18.08.2009 r.] (in Ukrainian)

\section{METHODOLOGICAL ASPECTS OF CHILD-CENTRIC PRINCIPLE IN THE PEDAGOGICAL SYSTEM OF VASYL SUKHOMLYNSKYI}

\author{
Inna Yashchuk \\ Doctor of Sciences (in Pedagogy), Professor, \\ Dean at the Faculty of Primary Education and Philology, \\ Khmelnitsky Pedagogical Academy for the Humanities, \\ Khmelnytskyi, Ukraine \\ ORCID: 0000-0003-4028-3327 \\ e-mail: yashchuk.ip@gmail.com
}

\footnotetext{
Abstract. The article deals with the methodical aspects of child-centric principle in the pedagogical system of Vasyl Sukhomlynskyi. The peculiarities of the didactic aspect of child-centric principle are considered as the unity of the following pedagogical phenomena: teaching as a system of activity in order to create conditions for students' educational and
} 
their cognitive activity; learning as a purposeful, motivated, self-regulating, transformative activity to master, transform, preserve and apply the system of knowledge, in the result of which the development and upbringing of the individual takes place; self-development of the participants in the leaning process as an active, consistent, progressive and irreversible change in the socio- psychological status of the individual of the student in the process of learning through the need for self-improvement.

It is found out that child-centric principle at Pavlysh school was realized on the basis of the teacher's knowledge of the personality of each student, the motivation of leaning, the support of his primary desire to learn; formation of knowledge which are necessary for selfrealization in society; orientation to the development of the individual characteristics of each child, contributing to his or her personal growth and successful self-realization in society; pedagogy of partnership between all participants of the educational process.

The peculiarities of the educational aspect of child-centric principle are revealed, which is to organize extracurricular and self-educational activities, consisting in the organization of extracurricular and self-educational activities, aimed at harmonious integration of interests of all participants in the educational process: a student who seeks free self-development and the preservation of his personality; school whose strategic goal is to provide students with knowledge that will contribute to their successful implementation in society; a society whose efforts are directed at the moral self-development of the individual; a state that is interested in making children a worthy citizen of their own country.

The reform of modern education being aimed at creative transformation of the personality, her self-realization and self-development, the potential of Vasyl Sukhomlynskyi's innovative and pedagogical system is obvious, which fully reveals the effectiveness of the implementation child-centric principle into the modern-day educational process.

Keywords: child-centric principle, V. O. Sukhomlynskyi, Pavlysh school, didactic and educational aspects, student's self-development.

Стаття надійшла до редакиії 24.09.2019 p. 